\title{
THE PUZZLE OF ICT DRIVEN INNOVATION IN THE PUBLIC SECTOR: HUNGARY'S CASE
}

\author{
András Nemeslaki ${ }^{1}$
}

\begin{abstract}
Public ICT (Information Communication Technologies) investments do not necessarily result in improvement of effectiveness or efficiency regarding public services. Hungary has been spending around 1,2 billion Euros using funds from the European Social Cohesion and Structural Funds during the period of 2007-2018 for modernizing its public administration. Taking the investments into other sectors as a comparison, this means that more than 25\% of ICT development projects go to the public sector, which is in the magnitude of the financial, commercial and media sectors of Hungary. While the effects of digital transformation are unquestionable in these latter sectors, effectiveness of public ICT spending is problematic. When we look at the measurement scoreboards used in the EU and UN, we find Hungary not even improved its position, but in some areas has lost competiveness and fell behind. In this paper we show using some elements of earlier findings in digital innovation studies on public administration, that four key factors should be analysed in detail to find out reasons behind this phenomenon, Infrastructural questions, although need constant development and improvement, do not seem to be key explaining factors of lack of productivity improvement. Nor the techno-legislative institutions seem to be obstacles in Hungary's case, but rather some alignment in policy objectives and consistency.
\end{abstract}

Keywords: digital innovation, public sector ICT, service and process innovation, Hungary

\section{Introduction}

European digital cohesion is a pivotal question in order to increase competition and social wellbeing. Digital transformation of the public sector, government services and administration is in the heart of the reforms of European countries, not only to have cheaper governments and reduce administrative burden, but to exploit new opportunities of technology innovation. Several programs on the EU level provide guidelines, action plans and funding mechanisms for member states to implement public policies for digitalization and ICT based transformation, like the Digital Agenda, H2020, and the E-government Action plan.

In the course of these programs Hungary has been spending around 1,2 billion Euros using funds from the European Social Cohesion and Structural Funds during the period of 2007-2018 for modernizing its public administration. Taking the investments into other sectors as a comparison, this means that more than $25 \%$ of ICT development projects go to the public sector. While in the effects of digital transformation are unquestionable in these latter sectors, effectiveness of public ICT spending is problematic. When we look at the measurement scoreboards used in the EU and UN, we find the Hungary not even improved its position, but in some areas has lost competiveness and fell behind in several rankings. We put this dilemma as the main question of our research.

${ }^{1}$ Technical University of Budapest, nemeslaki@finance.bme.com 
In this paper we enlighten the problem with the use of empirical data and systematically point out the areas which need to be addressed for future explorations, and for finding solutions for more effective ICT adoption in PA. Our focus is the special situation of Hungary, but using digital innovation as a theoretical framework we show that this analysis also has implications both beyond Hungary and for theory as well.

\section{Problem statement and research question}

Adoption of information communication technologies is a pivotal problem in public administration. While the concept of using information communication technologies (ICT) for improving efficiency of governmental services is as old, as ICT themselves [1] and often considered thoroughly researched [2], [3], we would like to develop arguments that this problem is highly relevant not only from a pragmatic public policy point of view but, very importantly, from a theoretical point as well.

Our key assumption is that low level of e-service adoption in governments, that is success in using ICTs for supporting public services, stem from lack of digital service innovation - an approach which considers the richness of the socio-economical change generated by technology development and allowing to go beyond the concepts of effectiveness and efficiency of existing services [4].

ICT deployment in public sector is triggered by policy objectives. Among many variations these are often administrative burden reduction, provision of better services, or enhancing economic development and innovation in the business sector. Attainment of these objectives are measured by aggregate statistical data combined using secondary and primary sources - the latter getting more relevant given the unique nature of digital transformation, which is often difficult to describe with standard macro economical statistics.

Performance of countries are measured and compared by several complex surveys. In this paper we are using two very commonly referred and used instruments two highlight the key problem what governments are facing. The first is the United Nations E-government Development Index (EGDI), and the second is the European Commissions Digital Economy and Society Index (DESI). In Hungary`s case both indicate serious dilemmas of ICT investment in the public sector.

EGDI assesses countries based three equally weighted indices; a) On-line services index, b) Telecommunication Infrastructure Index and c) Human Capital Index (HCI). Each contain further sub-indices which are than normalized to a scale of $0-1$. Based on these, a country ranking is also created, which is biannually presented in a detailed report analysing regions, special areas of public service and the detailed components of the indices. Since it is not the objective of this essay to analyse the EGDI surveys in detail, we draw the attention only to one of these analyses from the latest report available at the time of writing this manuscript [5]. 


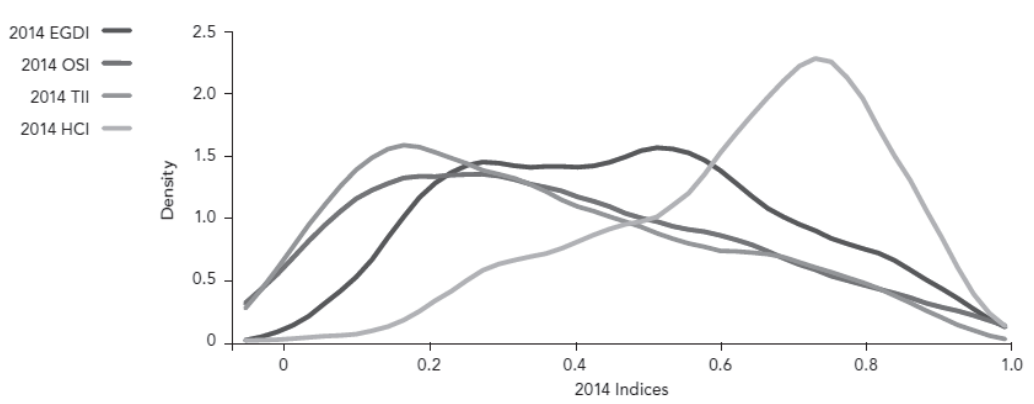

Figure 1: EGDI and its components [6]

As it is shown in figure 1 human capital scores are higher compared to the other two components. The lowest performing component is the Telecommunication Infrastructure Index (TII) which drags down the overall EGDI; while the Online Service Index (OSI) also trails in performance compared to the average value.

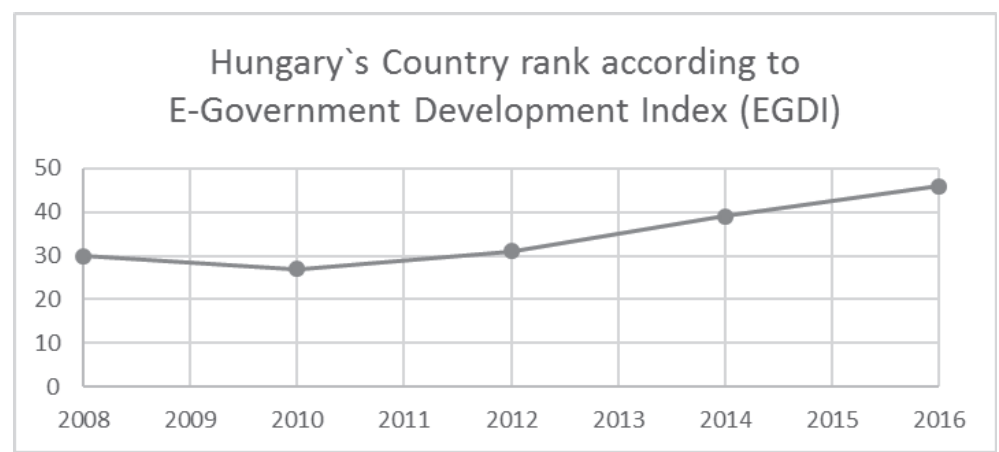

Figure 2: The assessment of Hungary's public ICT effectiveness based on EGDI (Created by the Author).

When we look at Hungary's assessment according to the UN EGDI reports - shown in figure 2- we see that the competitive position compared to others is steadily declining, from the 27th position in 2010 it fell back to the 46th in 2016. The performance is better, yet does not show relative improvement either, when we look at the other complex indicator, the DESI measure.

\begin{tabular}{|l|l|l|l|l|}
\hline Hungary DESI & 2014 & 2015 & 2016 & 2017 \\
\hline Connectivity and use & 10,9 & 13,4 & 14,9 & 15,9 \\
\hline Digital skills & 10,4 & 11,2 & 11,1 & 12,2 \\
\hline Use of Internet & 6,3 & 7,15 & 7,67 & 7,76 \\
\hline Integration of Digital Technology & 3,21 & 3,92 & 4,24 & 4,71 \\
\hline Digital Public Services & 5,2 & 4,32 & 4,97 & 5,32 \\
\hline DESI RANK & $\mathbf{2 1}$ & $\mathbf{2 0}$ & $\mathbf{2 0}$ & $\mathbf{2 1}$ \\
\hline
\end{tabular}

Table 1: Hungary's assessment according to the DESI indicators.

As we can see in table 1, DESI has five sub-indices: a) Network connectivity and use, b) digital skills, c) internet use, d) integration of digital technologies, and e) level of digitalized public services. Accordingly, DESI intends to assess a broad picture of ICT deployment than EGDI, it contains more data on enterprises and general ICT use amongst citizens. The last set of measures 
focus on the narrow definition of e-government or public services collecting four set of data in this field, these are:

- number of individuals using public e-services,

- $\quad$ number of finished on-line transactions,

- $\quad$ use of open data

- $\quad$ use of on-line forms.

Amongst the 27 countries measured Hungary's performance is steadily in $21-20^{\text {th }}$ position, however when we look at this last measure - the digital public services - we found Hungary in the $27^{\text {th }}$ place in 2017, which is a 7 places decline from the earlier measure in 2014.

In order to underline the real dilemma of the digitalization of public services we juxtapose the performance of EGDI and DESI measures with the financial investment which has been deployed during this period. As most Central Eastern European countries, Hungary also used mainly European Social Cohesion and Structural Funds for economic development. Two sources were dominant during the period of 2007-2013, and one source from 2013 onward.

- 173 million Euros were invested under the framework of the State Reform Operative Program in 2007-2013,

- 408 million Euros were invested as part of the Electronic Public Service Operative Program in 2007-2013 and

- $\quad 795$ million Euros are partly spent and partly allocated during the period of 2014-2018 called Public Service Operative Program.

For comparison, we quote the IT services report of IDC (International Data Corporation) which indicated that the total market for development projects in IT services was 363, 403 and 442 million Euros in 2016, 2017 and 2018 in Hungary [7]. Taking the annual averages of the public IT development projects (114 million Euros between 2007-2018), this roughly indicates that annually $28 \%$ of IT project spending goes to the government sector. However, compared to other sectors (financial services, retail or the media industry) the results and effects are much less significant as our data has shown.

In order to investigate the "puzzle of IT adoption in the public sector", in the following sections we take a closer look at some data sources, in order to find explanations and at the same time indicate direction of further investigations.

\section{Theoretical background of digital service innovation and the derived research model}

There is a consensus in the literature that provision of public e-services is determined by the interaction of four areas. The two main ones, which seem to be taken granted in most cases are the IT infrastructure [8] and the techno-legislative institutions (regulations such as interoperability and 
privacy) [9]. These two in our view are the "hard public administration requirements" or institutional determinisms. Beyond the hard requirements public organizations need "soft capabilities" as well. We consider two main sets of resources as part of these; first and foremost he human capacities of public administration to embrace the digital ecosystem at all levels - high level executives, mid-level management and personnel - including skills, knowledge and a mindset, [10], secondly the adoption of service oriented process management which efficiently cuts across silos of departments and organizations [11] [12]. Finally, awareness and adoption capability of citizens are essential to create a functioning public e-services ecosystem [13], [14], [15].

\begin{tabular}{|c|l|}
\hline ICT infrastructure & OK \\
\hline "Hard" infrastructure (network and equipment) & OK \\
\hline "Soft" infrastructure (STEM graduates and ICT specialists) & $? O K$ \\
\hline Techno-legal institutions (digital ecosystem) & OK \\
\hline Laws and regulations & OK \\
\hline Standards and procedures & OK \\
\hline Service oriented process management and process reengineering & $?$ \\
\hline Client side awareness and re-engineering & $?$ \\
\hline Internal process redesign and process re-engineering & $?$ \\
\hline Organizational learning and leadership capabilites & $?$ \\
\hline Knowlegde based service innovation & $?$ \\
\hline Management and leadership for directing change & $?$ \\
\hline
\end{tabular}

Table 2: Research Model for investigating the ICT innovation puzzle - Created by the Author

Based on these ideas we have established a research model presented in table 2. As far as data collection is concerned firstly, we looked at the latest report of the Hungarian Central Statistical Office which also serve as basis of for EuroStat data. We used the tables of "ICT equipment and use in public services", and throughout the paper we will refer to it as CSO-2016 [7] .

The second set has been a large scale representative survey conducted by the Hungarian Central Statistical Office the National University of Public Service (NUPS) during the last months of 2015 [16]. During the course of this 3800 citizens above the age of 18 were approached, of which 2160 successful data collection occurred at their homes. Cleansing and weighing for creating a representative set according to location, salary and gender has been calculated by the Measurement and Methodology Center of NUPS, and they generated tables for further analysis [17]. During the analysis we will refer to this as GGR-2016.

The third source, - and what we consider primary in our research - has been survey data of the Ministry of Interior which is responsible for e-service delivery. The survey was filled out by 1185 respondents, and the authors of the paper have processed the raw data by SPSS (Statistical Package for the Social Sciences).

\section{Discussion of results}

\subsection{ICT infrastructure}

Due to the continuous development of fix and mobile broadband technologies achieving a satisfactory network infrastructure is pivotal in the European Union. The Digital Agenda policy documents sets forth clear targets regardless both for coverage and penetration. Accordingly, by 
2020 the availability to access $30 \mathrm{Mbit} / \mathrm{sec}$ broadband at every household is articulated in the EU, while in $50 \%$ of these households the connection to $100 \mathrm{Mbit} / \mathrm{sec}$ is targeted. In Hungary, the Digital Wellbeing Program brings the first objective even 2 years earlier - the 30Mbit/sec coverage is targeted for 2018. The same document is also ambitious in mobile networks; it articulates that Hungary intends to be in the front runners of the $5^{\text {th }}$ generation implementors, although target dates are not announced.

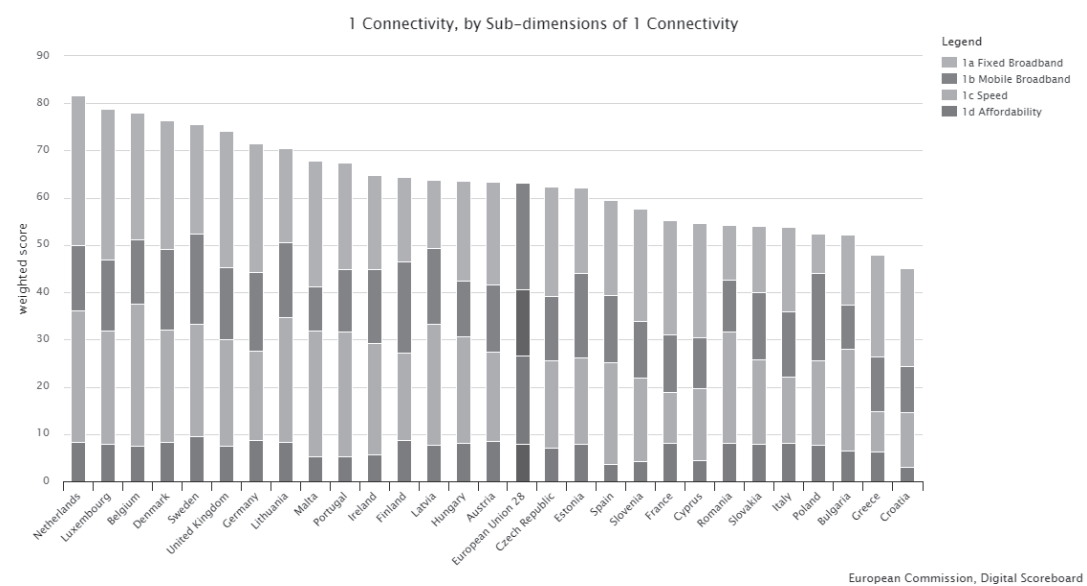

Figure 3: A glance look at ICT infrastructure - EU Digital Scoreboard 2017.

When we look at actual data describing connectivity, as is shown in figure 3, we can see that Hungary is basically average in EU comparison, actually improving its position between 2016 and 2017, closing up to its western neighbor, Austria.

In figure 4 we demonstrate that there are issues with STEM (Science-Technology-EngineeringMathematics) graduates and ICT specialist. In Hungary's case the STEM graduates are especially critical. compared to leading adopters such as Finland or UK, but even in regional comparison it looks suggestive that this area need further investigation. Basically all the new member states and the post-communist countries performing better in producing STEM graduates, and ICT specialists are also at the EU average.

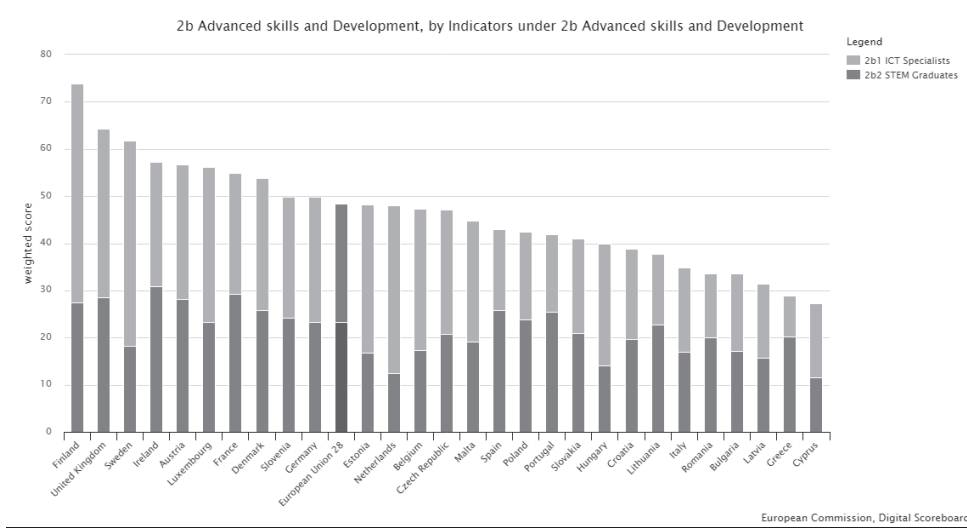

Figure 4: Special skills for ICT development: STEM graduates and ICT specialists - EU Digital Scoreboard 2017 
The gap in STEM graduates are critical, because most of the new jobs generated by AI development and smart automation will require skills such as analytical, data processing algorithm design, etc. large taught in engineering, mathematics or other fields of sciences. However, I would argue that other fields will adopt these skills, and the STEM dilemma will be not that relavent in the future, since sociology, business, economics and other social sciences quickly adopt data science, applied digital skill development or other ICT related skills into their curriculum.

As a conclusion here, we might state that Hungary's digital innovation dilemma is not rooted in infrastructure compared to other lead adopters, however the STEM-graduate dilemma might need to investigated in more detail.

\subsection{Techno-legal institutions}

Both qualitative expert opinions and empirical data underlines that the legislative institutional background is highly developed and enables digitalization a great deal in the Hungarian context. Hungary has put a lot of efforts for ensuring a modern and enabling legislative foundation for egovernment adoption.

Key legislative milestones - the legal platform for interoperability

The Magyary Zoltán Public Administration Development Programme ${ }^{2}$ contains the current situation of various public administration issues, actual problems to be solved, obstacles as well as strengths, potentials and real client needs. It initiates measures for interventions and several tools of development, such as one-stop-shops, redistribution of local and central powers, eGovernment, and human resource management. As a novelty, new building blocks had been introduced, the "regulated electronic administrative service" (Hungarian abbreviation: SZEÜSZ). SZEÜSZs are essential electronic services (front or even back office) from which complex electronic procedures and cases can be built. The governmental resolution contained the definition and basic requirements of the regulated electronic administration services, and also the list of the ones that the state (avoiding parallel developments) had to establish centrally. The mandatory SZEÜSZs are basically run by three major state organizations: the Central Office for Administrative and Electronic Public Services at the Ministry of Interior, the National Information and Communications Service Ltd. (NISZ Zrt.) and the Hungarian Post. Public administration institutions can use these services and integrate them into their own procedures. Some examples of regulated electronic administration services:

- Central Office for Administrative and Electronic Public Services: central authentication agent, timed client notification on electronic administration procedures, file validity register

- National Information and Communications Service Ltd.: government certificate authority (GOV CA), storage of e-documents, central form filling application

- Hungarian Post: secure delivery service, authentic conversion of paper documents into electronic form and vice versa

\footnotetext{
${ }^{2}$ http://magyaryprogram.kormany.hu
} 
To ensure interoperability between all the services and to protect the interests of the clients, the governmental resolution calls for the setting up of the Electronic Administration Authority. Its main task is to permit and to harmonize the development and the cooperation of the regulated electronic administration services.

\section{Focus and consistency of public policy}

In figure 5 we depict the results of the COCOPS (Coordinating for Cohesion in the Public Sector) survey, which was investigating the question amongst 2013 policy experts on how important digitalization is in their respected areas. As we can see, amongst the 10 participating countries Hungarian policy experts indicated the lowest importance for digitization, although the variation between the most important average (Italy) and Hungary as the lowest is 1,5 points on the 7 Likert scale.

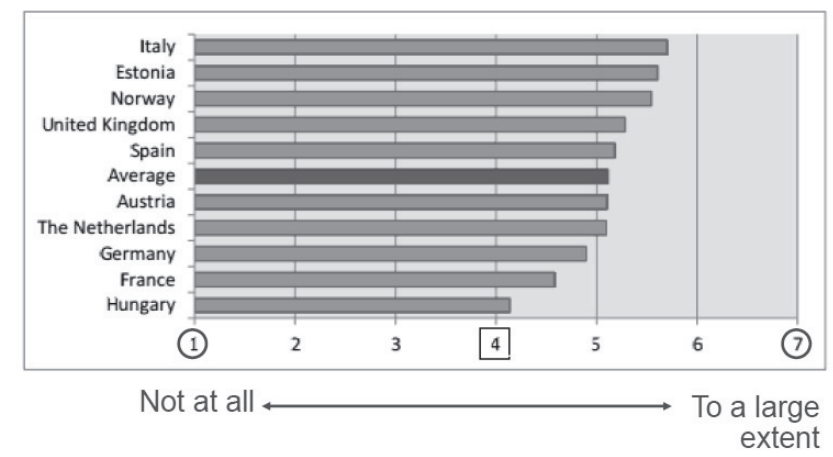

Figure 5: Importance of digital government according to the COCOPS survey [18].

\subsection{Service oriented process management and process re-engineering}

Client side awareness, use and skills

The key dilemma of Hungarian e-public service adoption is shown in figure 6. where we can notice that growth of on-line public service is basically determined by the use of internet users and their behavior; rate of access compared to the total number of population is not steeper or different in the two population, showing that there is no relative adoption gain from non-internet users for public eservice use in the period of 2006 and 2015.

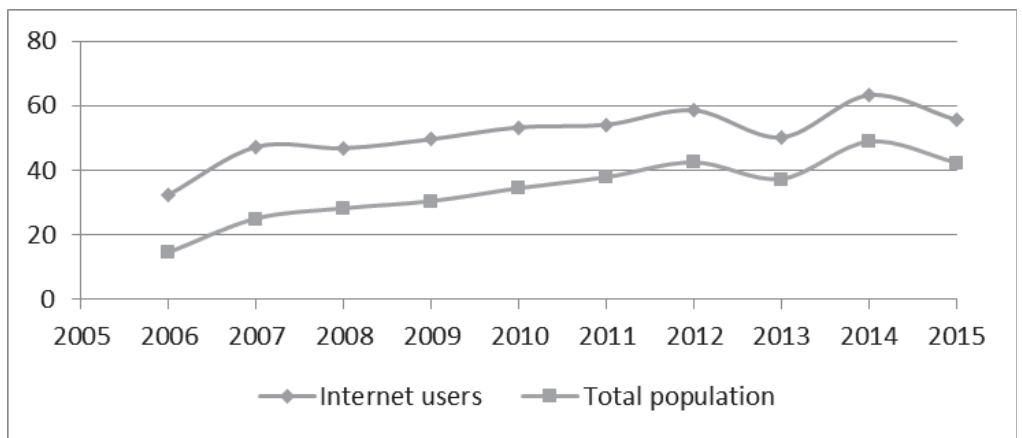

Figure 6: Usage of public e-portals \% of internet users and \% total population - Source: [7] 
Although the number of e-portal users do not seem too much, according the DESI Hungary belongs to the EU average countries, and not very far from more developed as Austria and surprisingly much ahead of Germany. One key questions arises to what extent citizens aware of on-line services? In [16], a panel of 2000 users were asked on a scale of 1-4 (not aware - totally aware) about on-line services and results are shown in figure 7 . The mean of the sample is 2,37 which is a "moderate level" of awareness.

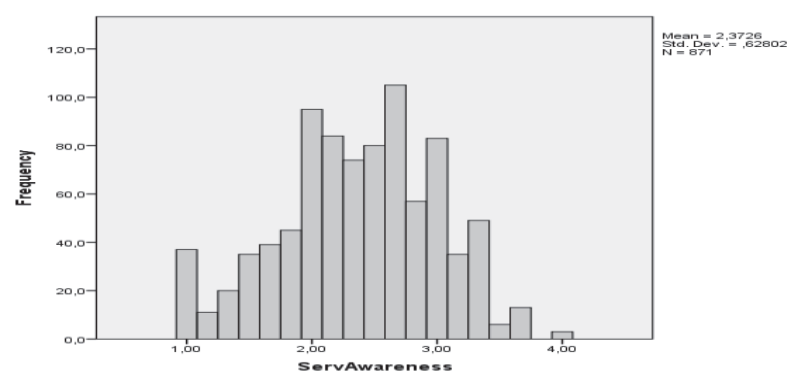

Figure 7: Awareness level of users about services - [16]

\section{Channel preferences}

As research shows in $2015,71 \%$ of the Hungarian population got in touch with public services. Mostly once, (31,5\%), twice (23,3\%) and much rarely three times or more (only 16,2\%). This indicates, that experience and judgement of public services is mostly based on few impressions solutions need to be intuitive, simple to use, requiring little effort even at the first time [16].

Looking at channel use and satisfaction, in table 3, we can observe that preference of using personal channels is more than half of the respondents, but satisfaction is highest amongst the on-line channel users. This shows the importance of conversion; it seems like once on-line channels are explored they score better than the experiences with the personal or even with the phone channels.

\begin{tabular}{|l|l|l|}
\hline Channels & Rate of usage (\%) & Satisfaction (0-10) \\
\hline Personal & 58 & 8,04 \\
\hline Postal & 21 & 8,34 \\
\hline Call center & 4 & 7,19 \\
\hline On-line & 18 & 8,62 \\
\hline
\end{tabular}

Table 3: Channel usage and statisfaction - Source: [16]

\section{Internal process design and re-engineering}

However, the importance of the management instruments varies significantly across countries. This is especially the case for internal steering by contract. While this is rather widely used in Italy (4.94), the Netherlands (4.92) and Hungary (4.40), internal steering by contract is rarely used in Spain (2.69) and Estonia (2.90) [18]. 


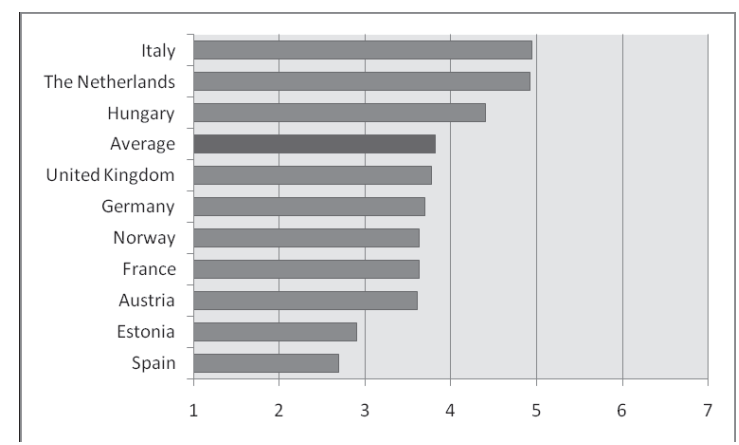

Figure 8: Importance of internal steering by contract (Q: To what extent is internal steering by contract used in your organization?; $1=$ Not at all, $7=$ To a large extent) [18]

Substantial country variation is also observable for the use of cost accounting systems. Such systems are rather widely used in the UK (5.25), Estonia (4.88) and Italy (4.54), but rarely used in Spain (2.86), Hungary (2.89) and France (3.15).

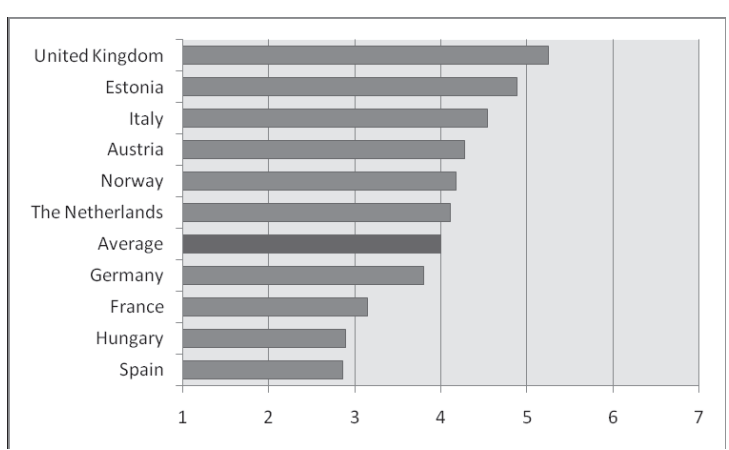

Figure 9: Importance of cost accounting systems $(Q$ : To what extent are cost accounting systems used in your organization?; $1=$ Not at all, $7=$ To a large extent) [18]

\subsection{Oganizational learning and leadership}

The COCOPS survey participants from Hungary reported, that public administration reforms are demanding in terms of management, but they prove to be successful [18].

Four groups can be distinguished. In one group of countries, consisting of Germany and Norway, the senior executives assess the reforms in their country as rather successful (albeit to a moderate degree) and as not demanding enough, especially compared with their colleagues in other countries. In a second group of countries, consisting of the Netherlands, Estonia and Hungary, the senior executives also consider the reforms as rather successful, but at the same time as too demanding. In a third group of countries, the senior executives are less satisfied with the reforms in their policy field; they consider them as rather unsuccessful and too demanding. This is especially the case for France, where downsizing and mergers are important (and demanding) reform trends that challenge many dimensions of the French administration. Senior executives in Spain, Italy and Austria assess the reforms in their countries as less successful and as rather not demanding enough. When considering the demandingness of reforms, it is important to keep in mind that it is not necessarily the number of reform trends a country introduces that determines the perception of demandingness, 
but that some reform trends (such as downsizing and mergers) are clearly more demanding than others (such as e-government or collaboration).

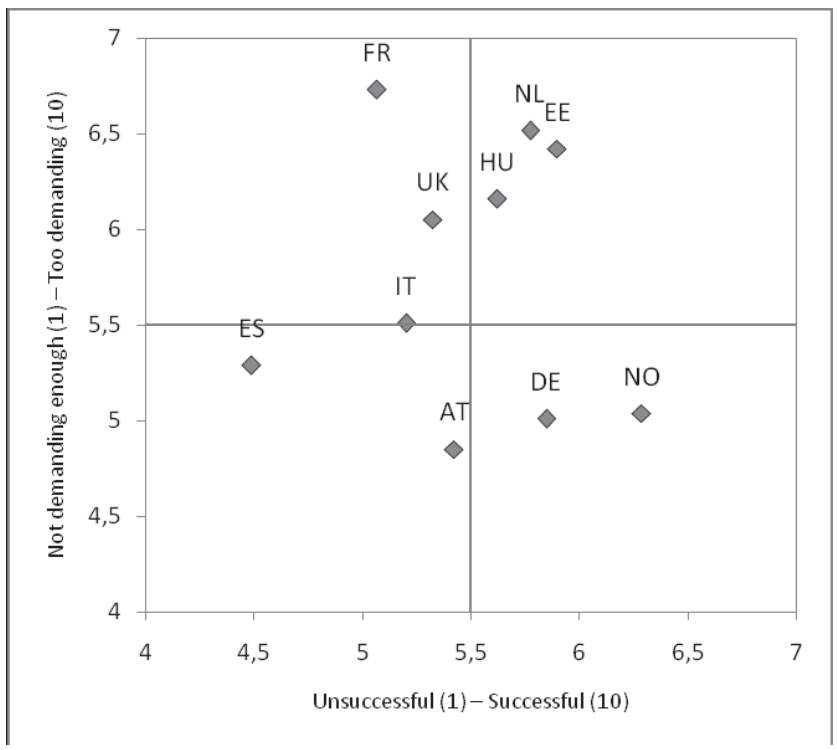

Figure 10: Dynamics of public sector reform: enough/too much vs. successful/unsuccessful [18]

\section{Knowledge based service innovation}

There are few data and research available on these dimensions of public organizations, especially in the context of technology driven or service driven innovation. Marton Gellén reported a study on interviewing and surveying Hungarian PA administrators on innovativeness and we summarize some of his results, which indicate the need for further study [19].

\begin{tabular}{|c|c|c|c|c|c|}
\hline Cluster names & Innovative & $\begin{array}{l}\text { No competition, } \\
\text { no outsourcing }\end{array}$ & No innovation & Average & Competitive \\
\hline Number of respondents in cluster & 2,036 & 1,416 & 984 & 1,961 & 1,836 \\
\hline $\begin{array}{l}\text { How important would you consider the follow- } \\
\text { ing: hierarchy and sticking to chain of command? }\end{array}$ & 4.49 & 4 & 3.08 & 3.93 & 4.05 \\
\hline $\begin{array}{l}\text { (...) compliance to internal bylaws and internal } \\
\text { instructions? }\end{array}$ & 4.79 & 4.52 & 3.48 & 4.53 & 4.55 \\
\hline $\begin{array}{l}\text { (...) relying on the expertise of the gov. civil } \\
\text { service? }\end{array}$ & 4.83 & 4.75 & 3.95 & 4.63 & 4.86 \\
\hline (...) impartiality, unbiased attitude? & 4.86 & 4.88 & 4.16 & 4.83 & 4.91 \\
\hline $\begin{array}{l}\text { (...) establishing competition among civil } \\
\text { servants? }\end{array}$ & 3.98 & 1.59 & 2.48 & 2.08 & 3.58 \\
\hline $\begin{array}{l}\text { (...) precisely defining individual performance } \\
\text { indicators? }\end{array}$ & 4.69 & 3.89 & 3.21 & 4.19 & 4.49 \\
\hline (...) outsourcing of tasks? & 4.17 & 1.42 & 2.64 & 3.75 & 1.83 \\
\hline (...) delegating tasks? & 4.49 & 3.55 & 3.25 & 4.04 & 4.16 \\
\hline (...) involving gov. civil servants into decisions? & 4.49 & 4.16 & 3.53 & 4.19 & 4.30 \\
\hline $\begin{array}{l}\text { (...) involving colleagues as partners in work } \\
\text { processes? }\end{array}$ & 4.76 & 4.6 & 3.91 & 4.61 & 4.69 \\
\hline $\begin{array}{l}\text { (...) cooperation with external professional } \\
\text { institutions and with social partners? }\end{array}$ & 4.58 & 4.01 & 3.33 & 4.35 & 4.43 \\
\hline $\begin{array}{l}\text { (...) establishing occasional work connections } \\
\text { with external institutions and with market players? }\end{array}$ & 4.32 & 3.18 & 3.02 & 3.87 & 3.92 \\
\hline
\end{tabular}

Figure 11: Innovativeness of Hungarian public service organizations [19] 


\section{Conclusions}

We have shown using some elements of earlier findings in digital innovation studies on public administration, that four key factors of table 2. should be analysed in detail to find out in-depth reasons behind this phenomenon. Infrastructural questions, although need constant development and improvement, do not seem to be key factors, explaining the lack of productivity improvement. Nor the techno-legislative institutions seem to be obstacles in Hungary's case, except some alignment in policy objectives and consistency.

Service oriented process management and knowledge driven organizational change, however, prove to be key obstacles for successful ICT adoption in digital governance.

\section{References}

[1] BANNISTER F ; CONNOLLY R, "Forward to the past: Lessons for the future of egovernment from the story so far," Information Polity, vol. 17, no. 3-4, pp. 211-226, 2012.

[2] JUKIC, T.; TODOROVSKI L.; NEMESLAKI, A. "Investigation of E-government Research Field: What Has Been Done and How to Proceed?," in 23rd NISPAcee Annual Conference, Tbilisi, Georgia, 2015. May 21-23, 2015.

[3] ZABUKOVSEK, S; BOBEK, S; VOSNER, S; SEBJAN, U. "Bibliometric Analysis of Egovernment Research," in Multi-Level (e) Governance: Is ICT a means to enhance transparency and democracy? CEE e-Dem and e-Gov Days 2016, Vienna-Budapest, 2016.

[4] BARRETT, M.; DAVIDSON, E.; PRABHU, J.; VARGO, L. "Service Innovation In The Digital Age: Key Contributions And Future Directions," MIS Quarterly, vol. 39, no. 1, pp. 135-154, 2015.

[5] UNITED NATIONS, United Nations E-Government Survey 2016, New York: UN Department of Economic and Social Affairs, 2016.

[6] UNPAN, "United Nations E-Government Survey 2014: E-Government for the Future we Want," United Nations Department of Economic and Social Affairs, New-York, 2014.

[7] RANA, N.; WILliAMS, M.; DWIVEDI, Y.; WILLIAMS, J. "Theories and Theoretical Models for Examining the Adoption of E-Government Services," e-Service Journal, vol. 8, no. 2, pp. 26-56, 2012.

[8] SZÁDECZKY, T. "Information Security - Strategy, codification and awareness," in ICT Driven Public Service Innovation, Budapest, Publisher of the National University of Public Service, 2014, pp. 99-112.

[9] KADAR, K.; “Good Governance: International Dimension”, Budapest: National University of Public Service, 2015. 
[10] DAVENPORT, T.: "Process Innovation: Reengineering work through information technology", Boston, MA: Harvard Business School Press, 1993.

[11] VANDER ELST, S.; DE RYNCK, F. "Diving in the Dynamics of Alignment Process in Public Organizations: Lessons for a Reconceptualized Alignment Framework," in EGPA Conference, Speyer, Germany, 2014.

[12] ALHARBI, A.; KANG, K.; HAWRYSZKIEWYCZ, I. "The Influence of Trust and subjective Norms on Citizens' Intentions to Engage in E-participation on E-government Websites," in Australasian Conference on Information Systems, Adalaide, 2015.

[13] LIN, F.; FOFANAH, S.; LIANG, D. “Assessing citizen adoption of e-Government initiatives in Gambia: A validation of the technology acceptance model in information systems success," Government Information Quarterly, vol. 28, no. 2, pp. 271-279, 2011.

[14] WELCH, E.; HINNANT, C.; MOON, J. "Linking Citizen Satisfaction with E-Government and Trust in Government," Journal of Public Administration Research and Theory, vol. 15, no. 3, p. 371-391, 2009.

[15] CSO, Az infokommunikációs technológiák és szolgáltatások helyzete Magyarországon 2015 (Status of ICT and related services in Hungary-2015) - in Hungarian, Budapest: Central Statistical Office, 2016.

[16] KAISER, T. Ed., “Jó Állam Jelentés (Good Governance Report) 2016 “- in Hungarian, Budapest: NKE Kiadó, Improved and Abridged Edition, 2016.

[17] CSUHAI, S. Ed., “Jelentés a Jó Állam Véleményfelmérésről (Report on the Opinion Survey of the Good Governance Report)" - in Hungarian, Budapest: NKE Kiadó, 2016.

[18] HAMMERSCHMID, G.; OPRISOR, A.; ŠTIMAC, V. "COCOPS Executive Survey on Public Sector Reform in Europe," Coordination for Cohesion in the Public Sector of the Future (COCOPS): www.cocops.eu, 7th Framework Programme, 2013.

[19] GELLÉN, M. "Bureaucrats As Innovators? Statistical Analysis On Innovative Capacity Within The Hungarian Central Civil Service," Transylvanian Review of Administrative Sciences, vol. Special Issue, pp. 38-54, 2016.

[20] MEDAGLIA, R. "eParticipation research: Moving characterization forward (2006-2011)," Government Information Quarterly, vol. 29, no. 3, p. 346-360, 2012.

[21] IRANI, Z.; WEERAKKODY, V.; KAMAL, M.; HINDI NITHAM, M.; ANOUZE, O.; EL-HADDADEH, R.; LEE, H.; OSMANI M.; AND AL-AYOUBI, B. "An analysis of methodologies utilised in e-government research: A user satisfaction perspective," Journal of Enterprise Information Management, vol. 25, no. 3, pp. 298-313, 2012. 
[22] BROWN, D. "Electronic government and public administration," International Review of Administrative Sciences, vol. 71, no. 2, p. 241.254, 2005.

[23] ARANYOSSY, M.; NEMESLAKI, A.; FEKÓ, A. "Empirical Analyis of Public ICT Development Project Objectives in Hungary," International Journal of Advanced Computer Science and Applications, vol. 5, no. 12, pp. 45-54, 2014.

[24] EUROPEAN COMMISSION, "Scoreboard 2014 - Developments in eGovernment in the EU 2014," 2805 2014. [Online]. Available: https://ec.europa.eu/digitalagenda/en/news/scoreboard-2014-developments-egovernment-eu-2014. [Accessed 2611 2014].

[25] NEMESLAKI, A. "The theory of "IT-Government Alignment": Assessment of strategic fit in Hungary's case," in Multi-Level (e) Governance: Is ICT a means to enhance transparency and democracy? CEE e-Dem and e-Gov Days 2016, Vienna-Budapest, 2016.

[26] CORDELLA, A.; TEMPINI, M. "E-government and organizational change: Reappraising the role of ICT and bureaucracy in public service delivery," Government Information Quarterly, vol. 32, no. 3, p. 279-286, 2015.

[27] BALTHASAR, A.; GOLOB, B.; HANSEN, H.; MÜLLER-TÖRÖK, R.; NEMESLAKI, A.; PICHLER, J.; PROSSER, A.; "Multi-Level (e) Governance: Is ICT a means to enhance transparency and democracy? CEE e-Dem and e-Gov Days 2016", A. Balthasar, B. Golob, H. Hansen, R. Müller-Török, A. Nemeslaki, J. Pichler and A. Prosser, Eds., ViennaBudapest: Austrian Computer Society, 2016, pp. 259-272.

[28] OCSKAY, GY. "ICT enabled cross-border governance," in ICT Driven Public Service Delivery: Comparative Approach Focusing on Hungary, Budapest, National University of Public Service, 2014, pp. 123-136.

[29] RODRIGUEZ, B.; MANUEL, P.; MEIJER, A. "Smart Governance: Using Literature Review and Empirical Analysis to Build a Research Model," SOCIAL SCIENCE COMPUTER REVIEW, vol. 34, no. 6, pp. 673-692, 2016.

[30] PEE, L.; KANKANHALLI, A. "Interactions among factors influencing knowledge management in public-sector organizations: A resource-based view.," Governement Information Quarterly, vol. 33, no. 1, pp. 188-199, 2016.

[31] KISILOWSKI, A.; KISILOWSKA, I. “Administrategia (in Hungarian)”, Budapest: HVG, 2017. 
[32] BRYNJOLFSSON, E.; MCAFEE, A.:"The Second Machine Age: Work, Progress, and Prosperity in a Time of Brilliant Technologies", New York, USA: W.W. Norton \& Company, 2014.

[33] KAPLAN, R.; NORTON, D.; "The Balanced Scorecard: Translating Strategy into Action", Boston, MA: President and Fellows of Harvard College, 1996.

[34] BEKKERS, V.; "Why does e-government looks as it does? looking beyond the explanatory emptiness of the e-government concept," Information Polity, vol. 17, no. 3-4, p. 329-342, 2012.

[35] BÉLANGER, F.; CARTER, L. "Digitizing Government Interactions with Constituents: An Historical Review of E-Government Research in Information Systems," Journal of the Association for Information Systems, vol. 13, no. 5, pp. 363-394, 2012.

[36] VIRILI, F.; SORRENTINO, M. "Value generation in e-government from service-based IT integration," Transforming Government: People, Process and Policy, vol. 3, no. 3, pp. $227-$ 247, 2009.

[37] NAMBISAN, S.; LYYTINEN, K.; MAJCHRZAK, A.; SONG, M. "Digital Innovation Managemement: Reinventing Innovation Management in a Digital World," MIS Quarterly, vol. 41, no. 1, pp. 223-238, 2017.

[38] BERTOT, J.; ESTEVEZ, E.; JANOWSKI, T. "Universal and contextualized public services: Digital public service innovation framework," Government Information Quarterly, vol. 33, no. 2, pp. 211-222, 2016.

[39] BARRETT, M.; DAVIDSON, E.; PRABHU, L.; VARGO, S. "Service Innovation in the Digital Age: Key Contributions and Future Directions," MIS Quarterly, vol. 39, no. 1, pp. 135-154, 2015.

[40] YOO, Y.; BOLAND, R.; LYYTINEN, K. MAJCHRZAK, R. "Organizing for Innovation in the Digitized World," Organization Science, vol. 23, no. 5, p. 1398-1408, 2012. 